\title{
An unusual casein kinase 1 from Trypanosoma cruzi epimastigotes
}

\author{
Irene Justiniano ${ }^{1}$, Karem Noris-Suarez ${ }^{2}$, Ana R. De Lima ${ }^{3}$, Victor T. Contreras ${ }^{3}$ and José Bubis ${ }^{2 *}$ \\ *Correspondence: jbubis@usb.ve \\ 'Departamento de Química, Universidad Simón Bolívar, Caracas, Venezuela. \\ ²Departamento de Biología Celular, Universidad Simón Bolívar, Caracas, Venezuela. \\ ${ }^{3}$ Laboratorio de Protozoología, Centro BioMolP, Facultad de Ciencias de la Salud, Universidad de Carabobo, Valencia, Venezuela.
}

\begin{abstract}
Background: CK1 enzymes are serine/threonine protein kinases that regulate numerous cellular processes. Although seven putative CK1 ortholog genes have been identified in the genome of Trypanosoma cruzi, the causative agent of Chagas' disease, only two parasite CK1 isoforms have been characterized to date.

Methods: T. cruzi epimastigotes were collected at the exponential phase of growth. The parasite clarified cytosolic fraction was separated by anion-exchange column chromatography, and the non-adsorbed fraction was rechromatographed on a second anion-exchange column. In order to identify the parasite casein kinases, ATP:phosphotransferase activity was evaluated by using dephosphorylated casein as substrate and $\left[\gamma^{-32} \mathrm{P}\right]$ ATP as cosubstrate. In addition, specific peptide substrates and inhibitors for higher eukaryotic CK1 and CK2 enzymes were employed to classify the purified T. cruzi protein kinase.

Results: A soluble protein kinase that uses casein as a substrate, and possesses an apparent molecular weight of 33,000, was purified from the exponential phase of growth of T. cruzi epimastigotes. The purified protein specifically phosphorylated P1 (sequence=RRKDLHDDEEDEAMSITA), a selective peptide substrate for CK1, but not P2 (sequence=RRRADDSDDDDD) which is a CK2 substrate, and was inhibited by $\mathrm{N}$-(2-amino-ethyl)-5-chloroisoquinoline-8-sulfonamide and 1-(8-chloro-5isoquinolinesulfonyl)piperazine, two specific inactivators of CK1. Consequently, the purified casein kinase was classified as a CK1 enzyme. Kinetic studies showed that the T. cruzi CK1 has a $\mathrm{K}_{\mathrm{m}}$ of $172.5 \pm 5.1 \mu \mathrm{M}, 0.2062 \pm 0.0051 \mathrm{mg} / \mathrm{ml}$ and $35.5 \pm 2.9$ $\mu \mathrm{M}$ for ATP, casein and P1, respectively. Interestingly, this CK1 was stimulated in the presence of about $0.1 \mathrm{mM}$ GTP or 5'-guanylylimidodiphosphate, but was inhibited at approximately $1 \mathrm{mM}$ of either of these guanine nucleotides. Additionally, this enzyme was more than $80 \%$ inactivated by low concentrations of heparin $(1 \mu \mathrm{M})$, which is a common inhibitor of CK2 enzymes. However, other inhibitors of mammalian CK2, such as emodin and 5,6-dichloro-1-beta-D-ribofuranosylbenzimidazole, only affected the parasite CK1 activity at the highest concentrations used. Our findings demonstrate that this CK1 from T. cruzi has a dual modulation by GTP and an unusual sensitivity for heparin.

Conclusions: A novel CK1 activity that functionally differs from previously characterized T. cruzi CK1 enzymes was purified from the exponential phase of growth of epimastigote forms.
\end{abstract}

Keywords: Trypanosoma cruzi, epimastigotes, CK1, casein kinase 1, protein kinase, signaling

\section{Introduction}

Trypanosoma cruzi is the etiological agent of Chagas' disease, which can cause acute illness and death, especially in young children. Patients usually develop a chronic form of the disease that affects most organs of the body, often causing fatal damage to the heart and digestive tract. T. cruzi is a protozoan possessing a complicated life cycle, in which the parasite undergoes various transformations in both the host and the insect vector. The parasite exists as extracellular flagellated epimastigotes and metacyclic trypomastigotes in the invertebrate host, and as trypomastigotes and intracellular non-flagellated amastigotes in the vertebrate host. Little information is available about the regulation of these complex cellular changes; but, as in higher eukaryotes, it is likely that these protozoans control processes such as metabolism, growth, differentiation, gene expression and other cellular events through the reversible phosphorylation of proteins.

CK1 (aka casein kinase 1) is a family of monomeric serine/ threonine-selective protein kinases. CK1 is evolutionary conserved within eukaryotes and regulates a plethora of cellular processes [1-4]. We have purified and characterized a CK1 enzyme from the stationary phase of growth of $T$. cruzi epimastigotes [5,6]. Additionally, Spadafora et al., [7] have cloned two CK1 isoforms from T. cruzi, TcCK1.1 and TCCK1.2, which appeared to be differentially expressed throughout the parasite life cycle by Northern blot analyses. Yet, database analysis of the complement of protein kinases in the T. cruzi genome identified seven putative CK1 protein kinase genes [8]. Here, we have purified a CK1 activity from the exponential phase of $T$. cruzi epimastigotes, which functionally differs from the parasite CK1 enzymes previously characterized by Calabokis et al., $[5,6]$ and Spadafora et al., [7], and might correspond to a mixed kinase activity.

\section{Methods}

Reagents and kits

[ $\left.\gamma^{-32} \mathrm{P}\right]$ ATP (3000 Ci/mmol), New England Nuclear or Amersham; milk dephosphorylated casein, leupeptin, benzamidine, 
Justiniano et al. Biochemical Compounds 2014,

http://www.hoajonline.com/journals/pdf/2052-9341-2-1.pdf

doi: $10.7243 / 2052-9341-2-1$

L-trans-epoxysuccinyl-leucylamido(4-guanidino)butane (E-64), phenyl methyl sulfonyl fluoride (PMSF), heparin, 5,6-dichloro1-beta-D-ribofuranosylbenzimidazole (DRB), emodin, ATP, GTP, 5'-guanylylimidodiphosphate (GMP-PNP), Q-sepharose, Sigma; N-(2-aminoethyl)-5-chloroisoquinoline-8-sulfonamide (CKI-7), 1-(8-chloro-5-isoquinolinesulfonyl)piperazine (CKI-8), Seikagaku America; P81 phosphocellulose chromatography paper, Whatman; OptiPhase Hisafe II (liquid scintillation counting solution), LKB; bicinchoninic acid BCA ${ }^{\mathrm{TM}}$ Protein Assay Kit, Pierce. As reported in its product information sheet, milk dephosphorylated casein was composed of a mixture of a-, $\beta-, \gamma^{-}$, and $\mathrm{k}$-caseins, which vary in molecular mass from 19 to $25 \mathrm{kDa}$. The P1 (sequence=RRKDLHDDEEDEAMSITA) and P2 (sequence $=$ RRRADDSDDDDD) peptides were generously donated by Dr. Susan S. Taylor (University of California, San Diego, U.S.A.). All other chemicals were of analytical grade.

\section{Parasites and culture conditions}

A non-cloned virulent Venezuelan strain of T. cruzi epimastigote forms (EPm strain) was used as the source of parasites. Briefly, epimastigotes were grown at $28^{\circ} \mathrm{C}$, in liver infusion tryptose medium. Epimastigotes were collected at the exponential phase of growth by centrifugation $(3,000 \times \mathrm{xg})$, at $4^{\circ} \mathrm{C}$, and washed twice with phosphate buffered saline solution $(0.15 \mathrm{M}$, $\mathrm{pH}$ 7.2). During the final wash, an aliquot of the resuspended epimastigotes was used to count the number of parasites using a hemocytometer. The final cell pellet was kept frozen at $-80^{\circ} \mathrm{C}$ until further use.

\section{Purification of the parasite CK1 activity by column chromatography}

T. cruzi epimastigotes $\left(5 \times 10^{8}\right)$ were extracted on ice by sonication in Buffer A [50 mM Tris- $\mathrm{HCl}$ (pH 8.0), 2 mM EDTA] in the presence of protease inhibitors (50 $\mu \mathrm{M}$ PMSF, 10 $\mu \mathrm{M}$ leupeptin, $10 \mu \mathrm{M} \mathrm{E}-64$ and $1 \mathrm{mM}$ benzamidine). The homogenate was centrifuged at $100,000 \mathrm{xg}$, for $1 \mathrm{~h}$, at $4^{\circ} \mathrm{C}$, to separate the resulting supernatant and pellet fractions. The supernatant containing the parasite soluble fraction was diluted four times with cold distilled water in order to lower its ionic strength, and chromatographed on a Q-sepharose column, previously equilibrated with Buffer B [50 mM Tris- $\mathrm{HCl}$ (pH 8,0), 2 mM EDTA and 5\% glycerol]. Then, the flow-through fraction was rechromatographed on another Q-sepharose column using the same conditions. After an extensive wash of the second column with Buffer B, the adsorbed proteins were eluted using a salt gradient from 0 to $1 \mathrm{M} \mathrm{NaCl}$ in Buffer $B$. Fractions were collected and preserved at $-80^{\circ} \mathrm{C}$ until assayed.

\section{In vitro kinase assay}

The reaction mixtures contained $50 \mathrm{mM}$ Tris- $\mathrm{HCl}(\mathrm{pH} 8.0), 20$ $\mathrm{mM} \mathrm{MgCl}, 20 \mathrm{mM} \mathrm{KF}, 30 \mu \mathrm{M}$ [Y-32P] ATP (specific activity $\approx 4000$ $\mathrm{cpm} / \mathrm{pmol})$ and the substrate $(1 \mathrm{mg} / \mathrm{ml}$ dephosphorylated casein, $300 \mu \mathrm{M}$ P1 or $40 \mu \mathrm{M}$ P2). Various concentrations of CKI-7, CKI-8, GTP, GMP-PNP, DRB, emodin and heparin were also included in the reaction mixtures to determine their effect on the purified enzyme. Following the addition of the enzyme-containing samples, the reactions were incubated for $30 \mathrm{~min}$, at $25^{\circ} \mathrm{C}$, and terminated by spotting an aliquot on Whatman P81 phosphocellulose papers $\left(2 \times 2 \mathrm{~cm}^{2}\right)$. The P81 papers were washed 3 times with $50 \mathrm{mM}$ phosphoric acid $(15$ min per wash), dried and analyzed for radioactivity by liquidscintillation counting. One unit of activity was defined as the amount of enzyme which catalyzed the incorporation of 1 pmol of inorganic phosphate from [ $\left.\gamma^{-32} \mathrm{P}\right]$ ATP per min. When casein was used as the substrate, an aliquot of the reaction was terminated by adding sample buffer $[60 \mathrm{mM}$ Tris- $\mathrm{HCl}$ (pH 6,8), 3\% sodium dodecyl sulfate (SDS), 29\% glicerol, 0,1\% bromophenol blue and $5 \% \beta$-mercaptoethanol] and separated by SDS-polyacrylamide gel electrophoresis (SDS-PAGE). Phosphorylated proteins were visualized by autoradiography.

Determination of $K_{m}$ and Vmax for ATP, casein and P1 In order to evaluate the $\mathrm{K}_{\mathrm{m}}$ and $\mathrm{Vmax}$ for ATP of the purified $T$. cruzi CK1, duplicate assays of three independent experiments were carried out in the presence of $2 \mathrm{mg} / \mathrm{ml}$ dephosphorylated casein and increasing amounts of ATP $(0-200 \mu \mathrm{M})$. In order to determine the $\mathrm{K}_{\mathrm{m}}$ and Vmax for casein and $\mathrm{P} 1$ of the parasite enzyme, duplicate assays of three independent experiments were performed in the presence of $60 \mu \mathrm{M} \mathrm{ATP}$, using various concentrations of dephosphorylated casein $(0-0.58 \mathrm{mg} /$ $\mathrm{ml}$ ) or P1 (0-160 $\mu \mathrm{M})$. Initial velocity data were obtained at room temperature. A control assay in which enzyme was substituted by water was included and the resulting counts were subtracted for each time point. The enzyme showed an increasing and linear kinase activity over the course of the experiments ( $15 \mathrm{~min}$ ). $\mathrm{K}_{\mathrm{m}}$ and $\mathrm{Vmax}$ values were assessed by regression analyses employing double-reciprocal LineweaverBurk plots constructed from initial rate measurements. Values were reported as the media \pm the standard deviation (SD).

\section{Miscellaneous procedure}

Protein concentration was determined using bovine serum albumin as protein standard and a BCA ${ }^{\mathrm{TM}}$ Protein Assay Kit, according to the instructions of the manufacturer. SDS-PAGE was carried out on $12 \%$ polyacrylamide slab gels [9], and the polypeptide bands were colored by Coomassie blue R-250 or silver staining.

\section{Results}

\section{Purification of a T. cruzi CK1 activity}

T. cruzi epimastigotes harvested at the exponential phase of growth were homogenized by sonication, and the soluble and particulate fractions were separated by centrifugation. When the kinase activity was evaluated using dephosphorylated casein as a substrate, about $68 \%$ of the initial casein kinase activity obtained in the parasite total lysate was maintained in the clarified cytosolic fraction (Table 1), while the remaining $\sim 30 \%$ of the activity was contained in the parasite particulate 
Justiniano et al. Biochemical Compounds 2014,

http://www.hoajonline.com/journals/pdf/2052-9341-2-1.pdf

Table 1. Purification of the T. cruzi CK1 enzyme.

\begin{tabular}{lllll}
\hline Sample & $\begin{array}{l}\text { Activity, } \\
\text { units }\end{array}$ & $\begin{array}{l}\text { Specific activity, } \\
\text { units/mg }\end{array}$ & $\begin{array}{l}\text { Yield, } \\
\%\end{array}$ & $\begin{array}{l}\text { Purification, } \\
\text { fold }\end{array}$ \\
\hline $\begin{array}{l}\text { Homogenate } \\
\begin{array}{l}\text { Clarified soluble } \\
\text { fraction }\end{array}\end{array}$ & 2282 & 3.0 & 100 & 1 \\
$\begin{array}{l}\text { Flow-through from } \\
\text { the first Q-sepharose } \\
\text { column }\end{array}$ & 155602 & 3.2 & 67.6 & 1.07 \\
\begin{tabular}{l} 
Purified CK1 (F30) \\
\hline
\end{tabular} & 18892 & 157433 & 6818.7 & 1789.7 \\
\hline
\end{tabular}

${ }^{\star}$ One unit of activity was defined as the amount of enzyme which catalyzed the incorporation of $1 \mathrm{pmol}$ of inorganic phosphate from $\left[\gamma^{-32} \mathrm{P}\right]$ ATP per min at $25^{\circ} \mathrm{C}$.

fraction. The resulting parasite soluble fraction was then chromatographed on a Q-sepharose anionic-exchange column, and two distinct peaks of casein kinase activity were obtained that eluted at 0.05 and $0.35 \mathrm{M} \mathrm{NaCl}$, respectively. Accordingly, these peaks were named Q-I and Q-II (Figure 1A). These results were similar to our previous findings using $T$. cruzi epimastigotes that were harvested at the stationary phase of growth [5]. Two synthetic peptides, P1 which is specific for $C K 1$, and $\mathrm{P} 2$ which is specifically recognized by CK2, were examined as substrates for Q-I and Q-II. As shown before by Calabokis et al., [5], when the fractions from the Q-sepharose column were assayed with P1 and P2, P1 was predominantly phosphorylated by the first peak, where as P2 was only phosphorylated by the second peak (Figure 1B). Addition of GTP (1 mM) to the kinase assay mixture, only inhibited the phosphorylation of casein by Q-II, and did not affect the Q-I peak (Figure 1C), implying that Q-II may use either GTP or ATP as a phosphate donor as has been reported for CK2 enzymes from other species. On the basis of these results, the Q-I and Q-II activity peaks were identified as CK1 and CK2 enzymes, respectively. The CK1 and CK2 enzymes corresponded to approximately 40 and $60 \%$ of the total casein kinase activity that eluted from the column.

After the separation on the first Q-sepharose column, a 68.2 and 100.9-fold increase in casein kinase activity was attained in the flow-through fraction when compared with the activities obtained in the homogenate and the clarified soluble extract, respectively (Table 1), suggesting that the soluble casein kinases were partially inhibited in the parasite clarified fraction. Based on these results, the chromatography on the first Q-sepharose column appeared to eliminate the enzyme inhibitor(s) together with most of the other contaminating soluble acidic proteins. The flow-through fraction was then rechromatographed on a second Q-sepharose column, and after an extensive wash, bound proteins were eluted using a salt gradient (Figure 2). Collected fractions were assayed for kinase activity using dephosphorylated casein as substrate, and as indicated in Figure 2, the profile shows a predominant peak of casein kinase activity that eluted at about $0.1 \mathrm{M} \mathrm{NaCl}$, which corresponded to fraction 30 (F30). A yield of about $12 \%$
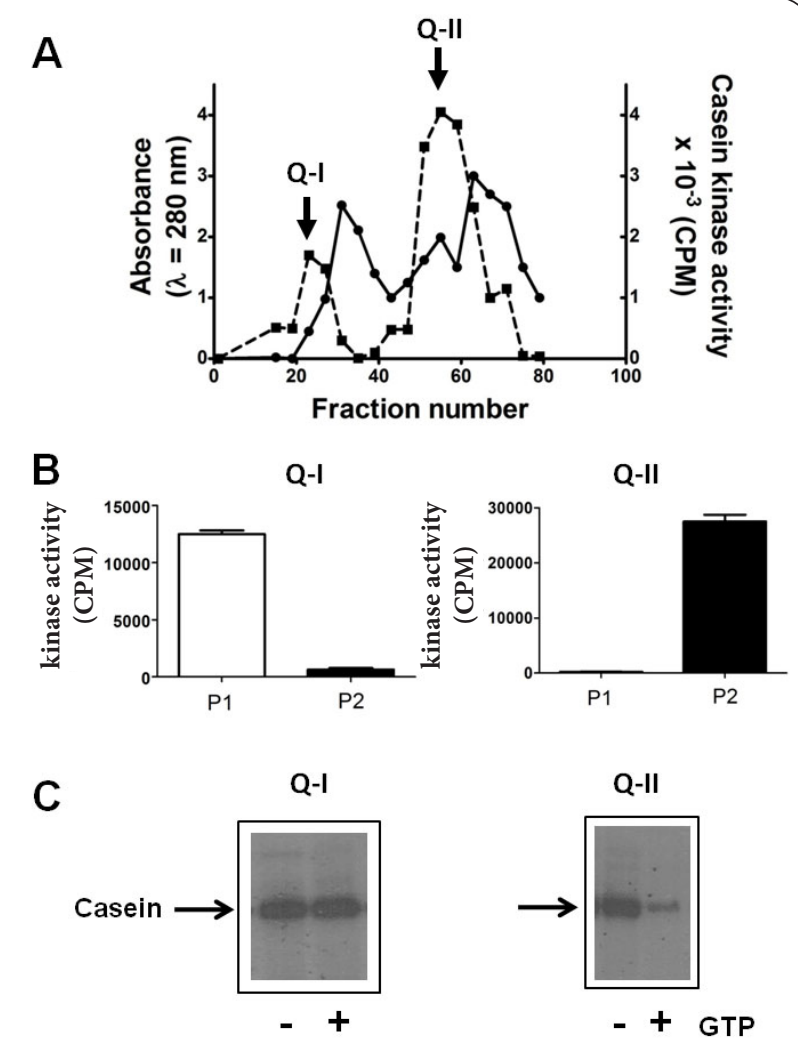

Figure 1. Q-sepharose chromatography.

(A) The clarified soluble extract from T. cruzi epimastigotes was loaded onto a Q-sepharose, and after washing extensively, elution began with a salt gradient. Fractions were collected and spectrophotometrically assayed for protein at $280 \mathrm{~nm}(\bullet)$, and for casein kinase activity by spotting the $\left[{ }^{32} \mathrm{P}\right]$ containing substrate on P81 phosphocellulose filters (CPM, -). Two peaks of enzymatic activity were obtained, which were named Q-I and Q-II, according to their order of elution from the salt gradient. (B) Fractions containing the Q-I and Q-II peaks were pooled, and aliquots $(30 \mu \mathrm{l})$ of each peak were assayed for kinase activity using the synthetic peptides P1 (white bars) and P2 (black bars). The average value resulting from triplicate determinations is shown. (C) Casein kinase activity of Q-I and Q-II was visualized by autoradiography, after SDS-PAGE separation of the radioactively-labeled exogenous substrate, in the absence (-) or presence (+) of 1 mM GTP.

of the initial casein kinase activity present in the flow-through fraction was recovered in the F30 peak, with a purification factor of $\sim 52480$ (Table 1).

The F30 casein kinase activity recognized effectively P1 (Figures 2 and $3 \mathrm{~A}$ ), whereas only a negligible phosphorylation signal was obtained when P2 was used as substrate (Figure 3A). The $\mathrm{F} 30$ casein kinase activity was also treated with $\mathrm{CKI}-7$ and $\mathrm{CKI}-8$, two specific inactivators of CK1 enzymes from mammals [10]. Complete inhibition of the purified activity was observed after 15-30 min pre-incubation with either $1 \mathrm{mM} \mathrm{CKI}-7$ or CKI-8 (Figure 3B). Control experiments in which $\mathrm{F} 30$ was incubated for 30 min with $10 \%$ dimethyl 
Justiniano et al. Biochemical Compounds 2014,

sulfoxide, the vehicle used to dissolve both CK1 inhibitors, produced no effect on its casein kinase activity (Figure 3B). The specificity for $\mathrm{P} 1$ and the inhibition by $\mathrm{CKI}-7$ and $\mathrm{CKI}-8$ demonstrated that the purified enzyme is a member of the protein kinase CK1 family. SDS-PAGE separation showed that the F30 fraction contained a major polypeptide band with an apparent molecular mass of $33 \mathrm{kDa}$, which was purified almost to homogeneity (Figure 2, Inset).

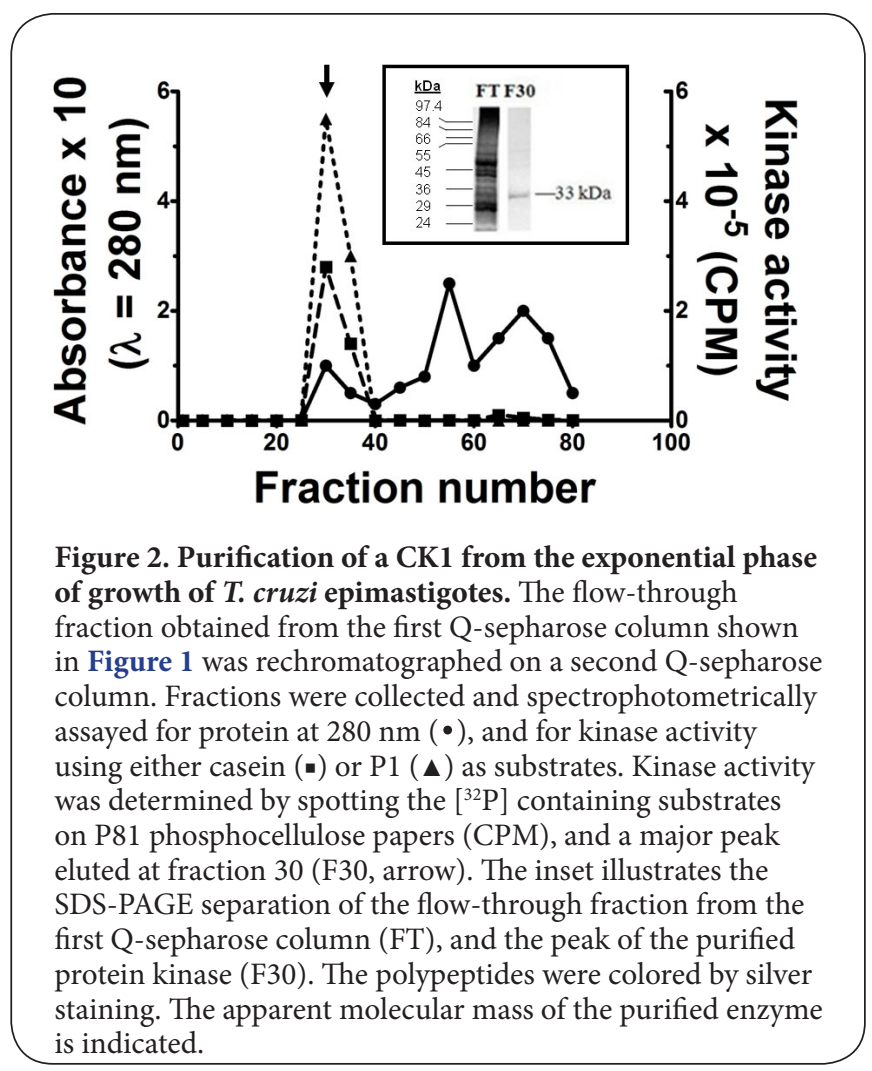

\section{Bioinformatics}

Seven genes that encode for CK1 proteins have been found on the T. cruzi genome [8]: 1) Tc00.1047053508541.220 or TcCLB.508541.220 that encodes for a protein with a molecular mass of $35.81 \mathrm{kDa}$, and corresponds to the TcCK1.1 isoform previously characterized [7]; 2) Tc00.1047053510247.20 or TCCLB.510247.20, that encodes for a protein of $41.91 \mathrm{kDa}$; 3) Tc00.1047053510089.170 or TcCLB.510089.170 (encoding for a protein of $47.64 \mathrm{kDa})$; 4) Tc00.1047053506945.110 or TCCLB.506945.110 (encoding for a protein of $44.1 \mathrm{kDa}$ ); 5) Tc00.1047053508541.240 or TCCLB.508541.240 (encoding for a protein of $38.12 \mathrm{kDa}$ ) that corresponds to the reported TcCK1.2 isoform [7] (this gene is identical to Tc00.1047053508541.230 or TCCLB.508541.230, which was initially identified as a different gene); 6) Tc00.1047053508541.225 or TcCLB.508541.225 (encoding for a protein of $31.89 \mathrm{kDa}$ ); and

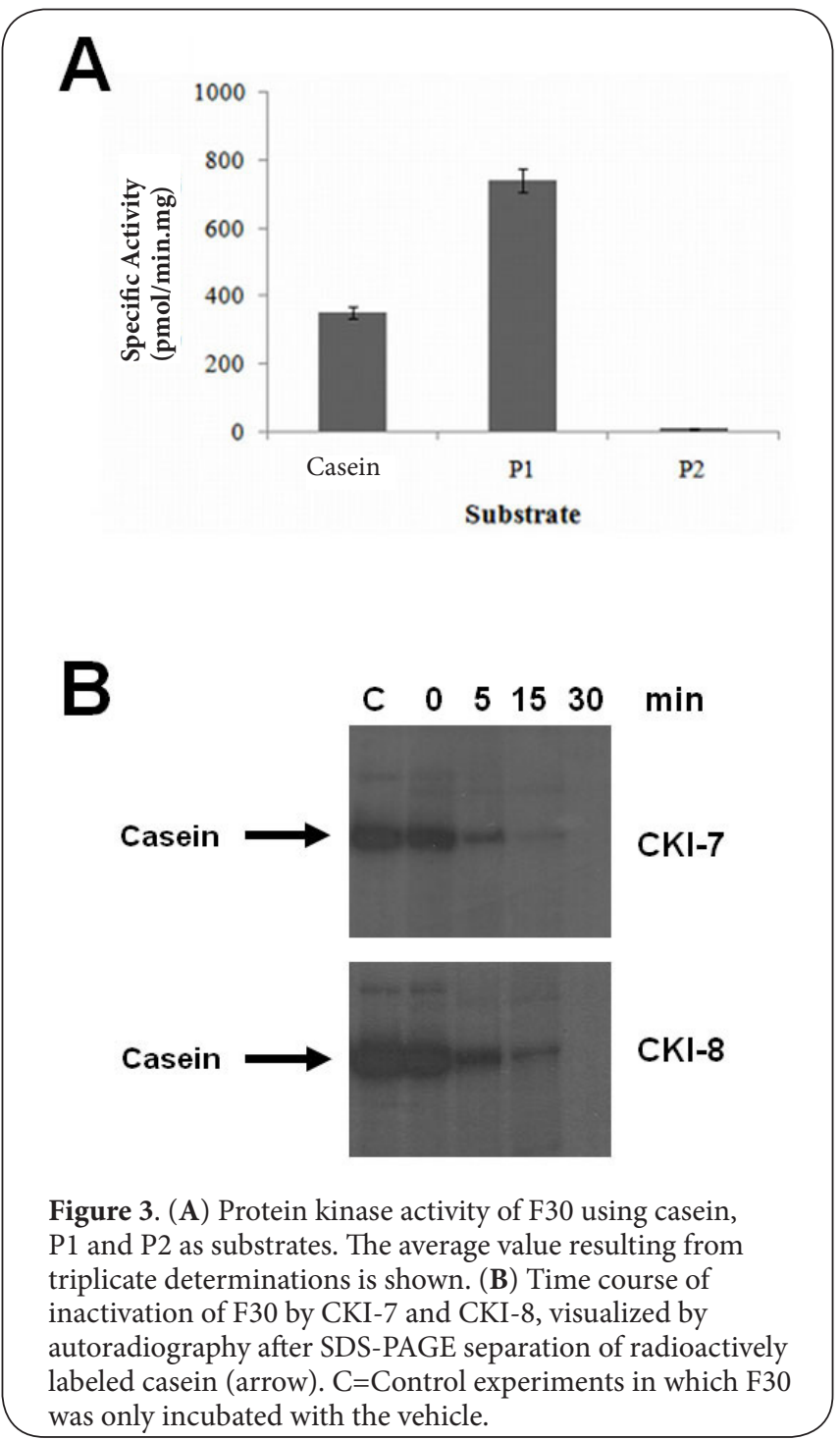

7) Tc00.1047053504057.170 or TcCLB.504057.170 (encoding for a protein of $73.41 \mathrm{kDa}$ ). Since an apparent molecular mass of $33 \mathrm{kDa}$ was determined for the purified T. cruzi CK1, this protein appears to correspond to the gene product of Tc00.1047053508541.225.

Kinetic characterization of the purified CK1 activity The kinase activity of $\mathrm{F} 30$ was characterized using increasing concentrations of the cosubstrate ATP, and the substrates dephosphorylated casein and P1. Michaelis-Menten curves were constructed (Figures 4, 5A and 5B), and the $\mathrm{K}_{m}$ and Vmax kinetic parameters for ATP, casein and P1 were determined using Lineweaver-Burk plots (Figures 4, 5A and 5B, Insets). The purified T. cruzi CK1 enzyme has a $\mathrm{K}_{\mathrm{m}}$ of $172.5 \pm 5.1 \mu \mathrm{M}$, $0.2062 \pm 0.0051 \mathrm{mg} / \mathrm{ml}$ and $35.5 \pm 2.9 \mu \mathrm{M}$ for ATP, casein and $\mathrm{P} 1$, respectively (Table 2 ). In addition, Vmax values of 

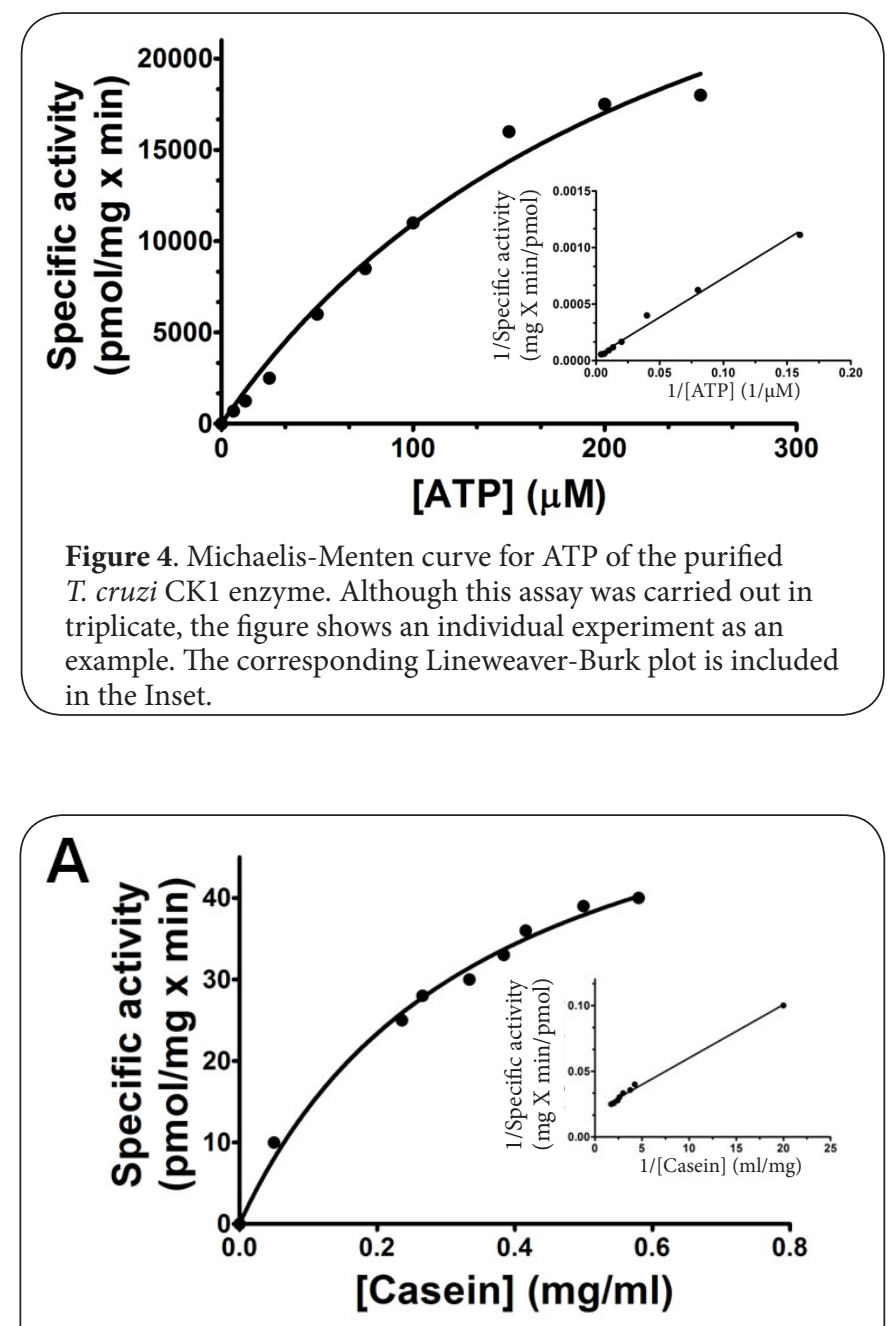

B

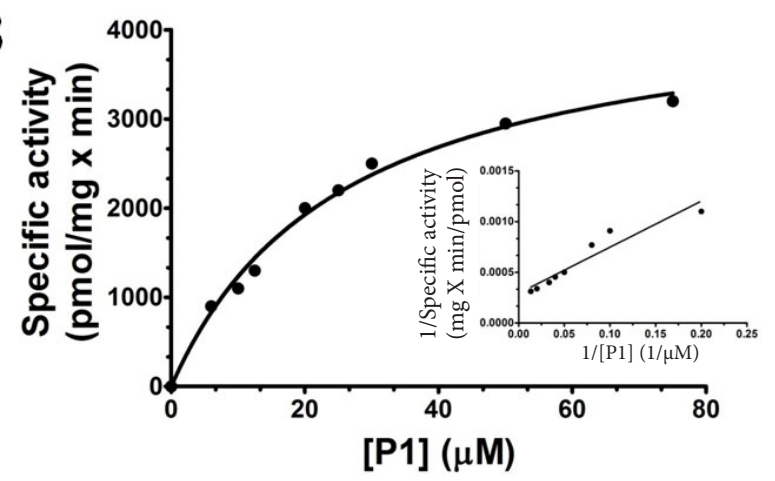

Figure 5. Michaelis-Menten curves for casein (A) and P1 (B) of the purified T. cruzi CK1 enzyme. Although both assays were carried out in triplicates, the figure shows individual experiments as examples. Lineweaver-Burk plots are included in the Insets.

$25000 \pm 1000 \mathrm{pmol} / \mathrm{mg} \cdot \mathrm{min}, 50.94 \pm 2.5 \mathrm{pmol} / \mathrm{mg} \cdot \mathrm{min}$ and $5000 \pm 300 \mathrm{pmol} / \mathrm{mg} \cdot \mathrm{min}$ were obtained for ATP, casein and P1. An unambiguous comparison between the substrates casein and P1 cannot be performed since commercial dephosphorylated casein contained a mixture of $\alpha-, \beta-$, $\mathrm{Y}^{-}$, and $\mathrm{K}$-casein isoforms, which varied in molecular mass from 19 to $25 \mathrm{kDa}$. Our results rendered a $\mathrm{K}_{\mathrm{m}}$ for casein of $0.2062 \pm 0.0051 \mathrm{mg} / \mathrm{ml}$, which corresponded to $9.37 \pm 0.23 \mu \mathrm{M}$ when $22 \mathrm{kDa}$, which is the average between 19 and $25 \mathrm{kDa}$, was used as the molecular mass of casein. Using this value, the $\mathrm{K}_{\mathrm{m}}$ for casein was approximately 4-fold lower than the $\mathrm{K}_{\mathrm{m}}$ for the peptide. Our results are consistent with previous reports involving other protein kinases since it generally has been observed that the $\mathrm{K}_{\mathrm{m}}$ values of protein kinases for their synthetic peptide substrates are higher than for their protein substrates. This may reflect the importance of higher-order structure in substrate recognition.

\section{Effects of GTP and GMP-PNP on the purified CK1 activity}

Given that GTP is an ATP-competitor for CK2 but not CK1 enzymes, and as such behaves like a CK2 inhibitor, we determined the effect of GTP on the casein kinase activity of F30. Autoradiography showed that $100 \mu \mathrm{M}$ GTP stimulated the enzymatic activity of the purified enzyme (Figure 6A). Quantitation by densitometry indicated that the incorporation of radioactive phosphate into casein increased 2.5 -fold in the presence of $100 \mu \mathrm{M}$ GTP (Figure 6B). On the other hand, an inhibition of this enzymatic activity was clearly seen at $1 \mathrm{mM}$ GTP (Figures 6A and 6B). Analyses using various concentration of GTP established that the activation of this kinase activity occurred in the range of 50-150 $\mu \mathrm{M}$ GTP (data not shown), and similar results were obtained by employing GMP-PNP, a non-hydrolyzable analog of GTP. The effect of GTP and GMP-PNP on the enzyme was also examined using P1 as a substrate. A stimulation of the P1 kinase activity of $\mathrm{F} 30$ was observed when 50-150 $\mu \mathrm{M}$ of GTP or GMP-PNP was utilized, and an inhibitory effect was obtained at about $1 \mathrm{mM}$ of these nucleotides (Table 2).

Table 2. Summary of kinetic properties of the purified CK1 from T. cruzi.

\begin{tabular}{llll}
\hline Reagent & $\mathbf{K}_{\mathrm{m}}(\mu \mathbf{M})^{\mathrm{a}}$ & $\mathbf{A C}(\mu \mathbf{M})^{\mathbf{d}}$ & $\mathbf{I C}_{50}(\mu \mathrm{M})^{\mathrm{e}}$ \\
\hline ATP (Cosubstrate) & $172.5 \pm 5.1$ & nd & nd \\
$\begin{array}{l}\text { Dephosphorylated casein } \\
\text { (Substrate) }\end{array}$ & $\sim 9.37 \pm 0.23^{\mathrm{b}}$ & nd & nd \\
P1 (Substrate) & $35.5 \pm 2.9$ & nd & nd \\
GTP (Activator and Inhibitor) & $\mathrm{nd}^{\mathrm{c}}$ & $\sim 100$ & $\sim 1000$ \\
GMP-PNP (Activator and & $\mathrm{nd}$ & $\sim 100$ & $\sim 1000$ \\
Inhibitor) & & & \\
Emodin (Inhibitor) & nd & nd & 130 \\
DRB (Inhibitor) & nd & nd & 50 \\
Heparin (Inhibitor) & nd & nd & $<1$ \\
\hline
\end{tabular}

${ }^{\mathrm{a}}$ Michaelis-Menten constant. ${ }^{\mathrm{b}}$ Since commercial casein contained four isoforms, an average molecular weight of 22,000 was used to calculate the $\mathrm{K}_{\mathrm{m}}$ for casein. ${ }^{\mathrm{c}} \mathrm{nd}=$ =not determined. ${ }^{\mathrm{d}}$ Activating concentration. ${ }^{\mathrm{e}} \mathrm{Half}$ maximal inhibitory concentration. 
Justiniano et al. Biochemical Compounds 2014,

http://www.hoajonline.com/journals/pdf/2052-9341-2-1.pdf

doi: $10.7243 / 2052-9341-2-1$

Activity of the purified CK1 in the presence of CK2 inhibitors

Emodin, DRB, and heparin are specific inhibitors for CK2 enzymes from higher eukaryotes [11-13]. Since GTP modulated the kinase activity of the purified CK1 from T. cruzi, we also analyzed its activity in the presence of increasing concentrations of emodin, DRB and heparin. The effects of these compounds were qualitatively determined by measuring the incorporation of radioactive phosphate into casein by autoradiography (Figure 6C). As illustrated in (Figure 6C), emodin and DRB affected the casein kinase activity of F30 at high concentrations. Quantitation by using P81 phosphocellulose papers and scintilliation counting showed that the purified T. cruzi CK1 had an IC ${ }_{50}=130 \mu \mathrm{M}$ for emodin and an $\mathrm{IC}_{50}=50$ $\mu \mathrm{M}$ for DRB (Table 2). Unexpectedly, very low concentrations of heparin $(1 \mu \mathrm{M})$ inhibited more than $80 \%$ of the enzymatic activity of the purified CK1 (Figure $6 \mathrm{C}$ and Table 2).

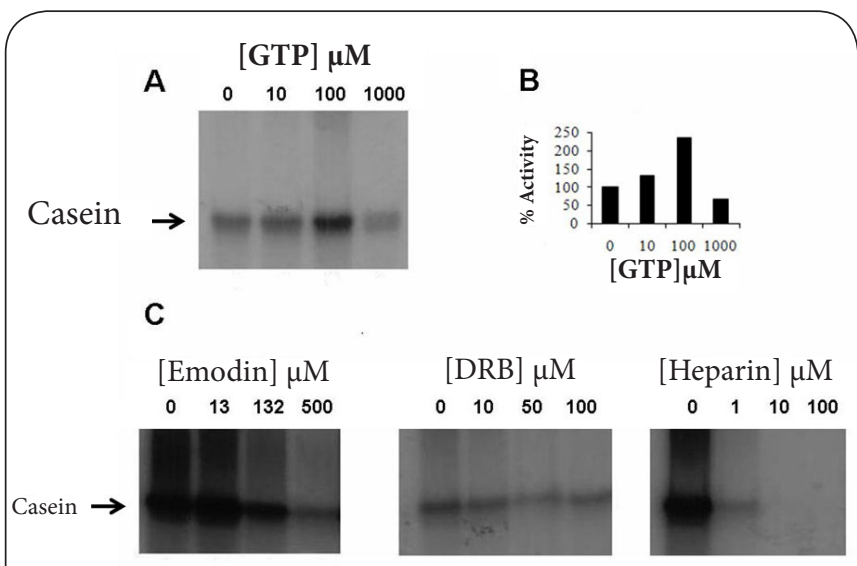

Figure 6. Effect of GTP and CK2 inhibitors on the casein kinase activity of the purified T. cruzi CK1.

The enzymatic activity was assayed in the absence or presence of various concentrations of GTP, using casein $(1 \mathrm{mg} / \mathrm{ml})$ as substrate (A and $\mathbf{B})$. In $(\mathbf{A})$ the effect of GTP $(0-1000 \mu \mathrm{M})$ on the casein kinase activity of the parasite CK1 was determined qualitatively by autoradiography following SDS-PAGE separation of the phosphorylated casein. (B) Quantitation by densitometry of the amount of phosphorylated casein attained in the experiment shown in (A). In (C) the kinase activity of the parasite CK1 enzyme was assayed using casein $(1 \mathrm{mg} / \mathrm{ml})$ as substrate, in the absence or presence of various concentrations of emodin $(0-500 \mu \mathrm{M})$, DRB $(0-100 \mu \mathrm{M})$ and heparin $(0-100 \mu \mathrm{M})$. The effect of the CK2 inhibitors on the kinase activity of the parasite CK1 was determined qualitatively by autoradiography after SDS-PAGE separation of the phosphorylated casein.

\section{Discussion}

The CK1 family of serine/threonine kinases is involved in many diverse and important cellular functions in eukaryotes, such as regulation of membrane transport, cell division, cytoskeleton maintenance, DNA repair, RNA metabolism, circadian rhythms, nuclear localization, Wnt signaling and parasitic infections [14]. Numerous parasites, including Toxoplasma spp. [15], Leishmania spp. [16,17], Trypanosoma spp. [5-7,18], Plasmodium spp. [19], and others, express CK1 orthologs. Bioinformatic analysis of the trypanosomatid genomes for the presence of protein kinases identified seven CK1 enzymes in T. cruzi, four in Trypanosoma brucei, and six in Leishmania major [8]. Through binding to and phosphorylation of a myriad of protein substrates, these CK1 protein kinases must regulate many parasite functions, and might play potential roles in the modulation of some host functions.

CKI was identified as an essential enzyme and a major putative target in T. cruzi, Leishmania mexicana, and other non-trypanosomatid parasites, such as Toxoplasma gondii and Plasmodium falciparum, by using affinity chromatography on resins containing immobilized purvalanol compounds [20]. Selective trisubstituted pyrrole and imidazopyridine compounds also inhbited the proliferation of L. major promastigotes and T. brucei bloodstream forms in vitro [21]. Biochemical studies have led to the discovery that the $L$. major CK1 isoform 2 (LmCK1.2, LmjF35.1010) represents the primary target of these inhibitors [21], and suggested that the homologous T. brucei enzyme (TbCK1.2, Tb927.5.800) may also be essential since the same inhibitors were also shown to be cytotoxic to T. brucei. Interestingly, induction of RNA interference targeted against TbCK1.2 in T. brucei bloodstream forms resulted in a rapid cessation of growth, gross morphological changes, multinucleation and ultimately cell death [22]. Parasite CK1 enzymes have also been implicated in shaping the interaction between the mammalian host and the infectious agents. Cytokines that belong to the interferon superfamily are important for efficient antiviral defense [23]. A CK1 activity secreted by L. major was capable of phosphorylating the degron of the IFNAR1 chain of the type I interferon receptor, inducing in turn its degradation [4]. Expression of $L$. major CK1 in mammalian cells stimulated the phosphorylation-dependent downregulation of IFNAR1 and attenuated its signaling. These results highlight the involvement of the parasite CK1 in the ligand-independent IFNAR1 degradation pathway. All these studies are of great interest given that targeting parasite protein kinases might be useful for developing novel antiparasitic agents [24].

Here, we have purified a CK1 from the exponential phase of growth of T. cruzi epimastigotes. Interestingly, this enzyme did not bind to the first Q-sepharose chromatography. On the contrary, this enzyme eluted in the flow-through fraction, which showed an increase in the casein kinase enzymatic activity obtained in the original parasite lysate and soluble clarified fraction. Our data implies that this particular CK1 enzyme is expressed in an inactive manner during the exponential growth phase of T. cruzi epimastigotes. Moreover, the enzyme inhibitor appears to be eliminated following 
the first anion-exchange chromatography column. The enzyme was adsorbed to the resin when the Q-sepharose flow-through fraction containing the activated casein kinase activity was applied to a second Q-sepharose column, and then, the enzyme was purified after the appropriate elution by increasing the ionic strength of the buffer. On the basis of kinetic measurements, this enzyme was different from the CK1 enzymes previously characterized from T. cruzi $[5,7]$. This novel enzyme has $\mathrm{K}_{\mathrm{m}}$ values of $172.5 \pm 5.1 \mu \mathrm{M}, 0.2062 \pm 0.0051$ $\mathrm{mg} / \mathrm{ml}$ and $35.5 \pm 2.9 \mu \mathrm{M}$ for ATP, casein and P1, respectively, which varied from the values previously reported for the purified CK1 enzyme from the stationary phase of growth of T. cruzi epimastigotes [5], and for the recombinant TcCK1.1 isoform [7], which appeared to represent the same CK1 enzyme (product of the Tc00.1047053508541.220 gene). Given that epimastigotes were collected here at the exponential phase of growth, whereas parasites were collected during the stationary phase of growth in the study reported by Calabokis et al., [5], the enzyme purified in this manuscript must correspond to another one of the seven different CK1 isoforms that are present in T. cruzi [8]. Based on its size, we suggest that the purified T. cruzi CK1 might correspond to the Tc00.1047053508541.225 gene product.

T. cruzi possesses a complicated life cycle, in which the parasite undergoes intricate morphological transformations in both the insect vector and the vertebrate host. The hematophagous insect vector ingests circulating trypo-mastigote forms, while feeding on blood from an infected vertebrate host. Once in the invertebrate digestive tract, ingested trypomastigotes differentiate initially to epimastigotes, a dividing and non-infectious form of T. cruzi. In a second differentiation process, known as metacyclogenesis, which occurs within the vector hindgut, epimastigotes are transformed to non-proliferative, infectious, metacyclic trypomastigotes. Spadafora et al., [7] analyzed the total parasite CKI activity during the cell growth of $T$. cruzi epimastigote forms, and reported that the CK1 activity increased in the exponential phase of growth until parasites reached the late exponential phase, at which point a drop in activity was observed. Moreover, they also showed through synchronization studies, that the CK1 activity has been most conspicuously circumscribed to the $S$ and $M$ phases of the cell cycle [7]. Epimastigotes growing in culture probably mimic the behavior of epimastigotes in the insect vector. During the exponential phase of growth, which is characterized by a high concentration of nutrients, the total population of parasites in culture must correspond to real proliferative epimastigotes. Nevertheless, in the late log or stationary phase of growth, epimastigotes probably differentiate to non-dividing and infectious metacyclic trypomastigotes, given that the amount of nutrients has extensively diminished and the environment probably approximates to the surroundings in the vector rectal gland. It is conceivable that the various T. cruzi CK1 genes are differentially expressed during the life stages of the parasite. Thus, the phase at which the epimastigotes are harvested might determine the type of CK1 isozyme that is predominantly expressed at that moment in the parasite. Protein posttranslational changes that may occur during the growth curve of the parasite could also be responsible of the differences in the functionality of these enzymes.

GTP is known to be used by CK2 enzymes as an alternative phosphate donor [11]. In contrast, no effect of GTP has been reported on CK1 enzymes from higher eukaryotes. Interestingly, when the purified parasite CK1 activity was examined in the presence of GTP, we initially observed an unusual activation on the enzymatic activity at concentrations of about $100 \mu \mathrm{M}$ of GTP, which was followed by an inhibition of its enzymatic activity at higher concentrations of GTP. A similar effect was reported for a casein kinase-like activity in crude extracts and particulate fractions of the Teva 1 isolate of Trypanosoma evansi, but not in its soluble fractions [18]. This effect was proposed to be caused by either a GTP-activated protein kinase or a GTP-dependent inactivation of a phosphatase. Given that we observed here the GTP stimulatory/inhibitory effect on the T. cruzi purified CK1 activity, we concluded that GTP directly regulates this unusual parasite enzyme probably by an allosteric mechanism. To determine if the GTP dual modulation was affected by the hydrolysis of GTP, we also employed GMP-PNP, a non-hydrolyzable analog of GTP. Interestingly, the stimulatory/inhibitory effect was identical using either GTP or GMP-PNP. T cruzi CK1 sequences show high homology with other eukaryotic CK1 enzymes, except for the insertion of three residues, Gly-Gly-Val (GGV), in the nucleotide binding domain of the T. cruzi proteins (residues 63-65 in TcCK1.1 and 65-67 in TcCK1.2) [7]. The gene product of Tc00.1047053508541.225 also contains the GGV insertion (residues 65-67). These three amino acids are absent in CK1 enzymes from other organisms, such as humans, Schizosaccharomyces pombe, Arabidopsis thaliana, Drosophila melanogaster, and P. falciparum [7]. Since the presence of glycines is typical of regions that are normally involved in the binding of nucleotides, this glycine-enriched sequence might be involved in the GTP binding pocket or regulate the binding of GTP. However, TCCK1.1 possesses the GGV insertion but is not modulated by GTP.

The purified CK1 activity was also examined in the presence of specific CK2 inhibitors, such as heparin $\left(\mathrm{IC}_{50}=0.1 \mu \mathrm{M}\right)[25]$, emodin $\left(\mathrm{IC}_{50}=2 \mu \mathrm{M}\right)$ [12] and DRB $(\mathrm{Ki}=23 \mu \mathrm{M})$ [13]. Results obtained for emodin and DRB are those expected for a CK1 type of enzyme. In contrast, the results obtained for heparin were unexpected and different than those obtained by Calabokis et al., [5]. Calabokis et al., [5] observed an inhibition of 70\% in the reported CK1 activity by using high concentrations of heparin $(\geq 200 \mu \mathrm{g} / \mathrm{ml}$ or $12.8 \mu \mathrm{M})$, whereas the CK1 activity reported in this work was reduced by more than $80 \%$ using only $1 \mu \mathrm{M}$ of heparin. Spadafora et al., [7] also showed that heparin slightly diminished TcCK1.1 activity by 10\% at the highest concentration used $(30 \mu \mathrm{g} / \mathrm{ml}$ or $1.92 \mu \mathrm{M})$. These results confirm that the CK1 reported here is different from 
Justiniano et al. Biochemical Compounds 2014,

http://www.hoajonline.com/journals/pdf/2052-9341-2-1.pdf

doi: $10.7243 / 2052-9341-2-1$

the TcCK1.1 isoform and the CK1 enzyme purified from the stationary phase of growth of T. cruzi epimastigotes.

Different isoforms of the same protein have distinct and non-redundant biological functions, and specificity for CK1 signaling is probably achieved in large part by isoform diversity. By culturing and harvesting epimastigotes at either the exponential phase or the stationary phase of growth, we are now capable of purifying two different CK1 isozymes from T. cruzi. Identifying the proteins that are phosphorylated by each of these CK1 isoforms, and recognizing the effect of such phosphorylations, may offer the best approach to understand the cellular roles of these protein kinases, which are attractive targets for antiparasitic drug discovery.

\section{Conclusions}

Although seven putative CK1 orthologs have been identified in the $T$. cruzi genome, only two isoforms have been biochemically studied to date. In this work, we purified a CK1 enzyme from the exponential phase of $T$. cruzi epimastigotes, which functionally differs from the parasite CK1 enzymes previously characterized. Little is known about the mechanisms that regulate CK1 activity, and this is the first time that a regulatory role of GTP is reported for this kinase. In addition, this enzyme possesses an unusual sensitivity for heparin, a common inhibitor of CK2 enzymes from higher eukaryotes. Hence, our results suggest that this novel CK1 enzyme might correspond to a mixed kinase activity. Different isoforms of the same protein probably have distinct and non-redundant biological functions, and specificity for CK1 signaling must be achieved in large part by isoform diversity. Through binding to and phosphorylation of a diversity of protein substrates, these CK1 protein kinases must play potential roles in the regulation of many T. cruzi functions, and might also modulate some host functions.

\section{List of abbreviations}

E-64: L-trans-epoxysuccinyl-leucylamido(4-guanidino)butane PMSF: phenyl methyl sulfonyl fluoride

DRB: 5,6-dichloro-1-beta-D-ribofuranosylbenzimidazole GMP-PNP: 5'-guanylylimidodiphosphate

CKI-7: N-(2-aminoethyl)-5-chloroisoquinoline-8-sulfonamide CKI-8: 1-(8-chloro-5-isoquinolinesulfonyl)piperazine

SDS: sodium dodecyl sulfate

SDS-PAGE: SDS-polyacrylamide gel electrophoresis

\section{Competing interests}

The authors declare that they have no competing interests.

Authors' contributions

\begin{tabular}{|l|c|c|c|c|c|}
\hline Authors' contributions & IJ & KNS & ARD & VTC & JB \\
\hline Research concept and design & -- & $\checkmark$ & -- & -- & $\checkmark$ \\
\hline Collection and/or assembly of data & $\checkmark$ & $\checkmark$ & $\checkmark$ & $\checkmark$ & $\checkmark$ \\
\hline Data analysis and interpretation & $\checkmark$ & $\checkmark$ & -- & -- & $\checkmark$ \\
\hline Writing the article & $\checkmark$ & $\checkmark$ & -- & -- & $\checkmark$ \\
\hline Critical revision of the article & -- & -- & -- & -- & $\checkmark$ \\
\hline Final approval of article & $\checkmark$ & $\checkmark$ & $\checkmark$ & $\checkmark$ & $\checkmark$ \\
\hline Statistical analysis & $\checkmark$ & -- & -- & -- & -- \\
\hline
\end{tabular}

Acknowledgement and funding

This work was supported in part by grants from FONACIT (No S1-99001075 and No LAB-2000001639), and Misión Ciencia ( ${ }^{\circ}$ 2007000960). We would like to thank Dr. Deisy Perdomo for helping with the illustrations, and Dr. Susan S. Taylor (University of California, San Diego, USA) for generously supplying the synthetic peptides P1 and P2.

\section{Publication history}

Editors: Ajoy Basak, University of Ottawa, Canada. Leonid Breydo, University of South Florida, USA. Received: 31-Oct-2013 Revised: 22-Nov-2013 Re-Revised: 14-Dec-2013 Accepted: 20-Dec-2013 Published: 21-Jan-2014

\section{References}

1. Knippschild U, Gocht A, Wolff S, Huber N, Lohler J and Stoter M. The casein kinase 1 family: participation in multiple cellular processes in eukaryotes. Cell Signal. 2005; 17:675-89. I Article I PubMed

2. Price MA. CKI, there's more than one: casein kinase I family members in Wnt and Hedgehog signaling. Genes Dev. 2006; 20:399-410. | Article I PubMed

3. Gallego $M$ and Virshup DM. Post-translational modifications regulate the ticking of the circadian clock. Nat Rev Mol Cell Biol. 2007; 8:139-48. | Article | PubMed

4. Liu J, Carvalho LP, Bhattacharya S, Carbone CJ, Kumar KG, Leu NA, Yau PM, Donald RG, Weiss MJ, Baker DP, McLaughlin KJ, Scott P and Fuchs SY. Mammalian casein kinase $1 \alpha$ and its leishmanial ortholog regulate stability of IFNAR1 and type I interferon signaling. Mol Cell Biol. 2009; 29:6401-12. | Article | PubMed Abstract | PubMed Full Text

5. Calabokis M, Kurz L, Wilkesman J, Galan-Caridad JM, Moller C, Gonzatti $\mathrm{MI}$ and Bubis J. Biochemical and enzymatic characterization of a partially purified casein kinase-1 like activity from Trypanosoma cruzi. Parasitol Int. 2002; 51:25-39. | Article | PubMed

6. Calabokis M, Kurz L, Gonzatti MI and Bubis J. Protein kinase CK1 from Trypanosoma cruzi. J Protein Chem. 2003; 22:591-9. I Article I PubMed

7. Spadafora C, Repetto Y, Torres C, Pino L, Robello C, Morello A, Gamarro $\mathrm{F}$ and Castanys $\mathrm{S}$. Two casein kinase 1 isoforms are differentially expressed in Trypanosoma cruzi. Mol Biochem Parasitol. 2002; 124:2336. | Article I PubMed

8. Parsons M, Worthey EA, Ward PN and Mottram JC. Comparative analysis of the kinomes of three pathogenic trypanosomatids: Leishmania major, Trypanosoma brucei and Trypanosoma cruzi. BMC Genomics. 2005; 6:127. | Article | PubMed Abstract | PubMed Full Text

9. Laemmli UK. Cleavage of structural proteins during the assembly of the head of bacteriophage T4. Nature. 1970; 227:680-5. I Pdf I PubMed

10. Chijiwa T, Hagiwara M and Hidaka H. A newly synthesized selective casein kinase I inhibitor, $\mathrm{N}$-(2-aminoethyl)-5-chloroisoquinoline-8sulfonamide, and affinity purification of casein kinase I from bovine testis. J Biol Chem. 1989; 264:4924-7. | Article | PubMed

11. Pinna LA. A historical view of protein kinase CK2. Cell Mol Biol Res. 1994; 40:383-90. | PubMed

12. Yim H, Lee $\mathrm{YH}$, Lee $\mathrm{CH}$ and Lee SK. Emodin, an anthraquinone derivative isolated from the rhizomes of Rheum palmatum, selectively inhibits the activity of casein kinase II as a competitive inhibitor. Planta Med. 1999; 65:9-13. | Article | PubMed

13. Sarno S, Moro S, Meggio F, Zagotto G, Dal Ben D, Ghisellini P, Battistutta $R$, Zanotti $G$ and Pinna $L A$. Toward the rational design of protein kinase casein kinase-2 inhibitors. Pharmacol Ther. 2002; 93:159-68. | Article | PubMed

14. Cheong JK and Virshup DM. Casein kinase 1: Complexity in the family. Int J Biochem Cell Biol. 2011; 43:465-9. | Article | PubMed

15. Donald RG, Zhong T, Meijer L and Liberator PA. Characterization of two 
Justiniano et al. Biochemical Compounds 2014,

T. gondii CK1 isoforms. Mol Biochem Parasitol. 2005; 141:15-27. | Article I PubMed

16. Sacerdoti-Sierra N and Jaffe CL. Release of ecto-protein kinases by the protozoan parasite Leishmania major. J Biol Chem. 1997; 272:30760-5. | Article | PubMed

17. Vieira LL, Sacerdoti-Sierra N and Jaffe CL. Effect of $\mathrm{pH}$ and temperature on protein kinase release by Leishmania donovani. Int J Parasitol. 2002; 32:1085-93. | Article | PubMed

18. Galan-Caridad JM, Calabokis M, Uzcanga G, Aponte F and Bubis J. Identification of casein kinase 1, casein kinase 2, and cAMP-dependent protein kinase-like activities in Trypanosoma evansi. Mem Inst Oswaldo Cruz. 2004; 99:845-54. | Article | PubMed

19. Kappes B, Doerig CD and Graeser R. An overview of Plasmodium protein kinases. Parasitol Today. 1999; 15:449-54. | Article | PubMed

20. Knockaert M, Gray N, Damiens E, Chang YT, Grellier P, Grant K, Fergusson D, Mottram J, Soete M, Dubremetz JF, Le Roch K, Doerig C, Schultz P and Meijer L. Intracellular targets of cyclin-dependent kinase inhibitors: identification by affinity chromatography using immobilised inhibitors. Chem Biol. 2000; 7:411-22. | Article | PubMed

21. Allocco JJ, Donald R, Zhong T, Lee A, Tang YS, Hendrickson RC, Liberator $P$ and Nare B. Inhibitors of casein kinase 1 block the growth of Leishmania major promastigotes in vitro. Int J Parasitol. 2006; 36:124959. | Article | PubMed

22. Urbaniak MD. Casein kinase 1 isoform $\mathbf{2}$ is essential for bloodstream form Trypanosoma brucei. Mol Biochem Parasitol. 2009; 166:183-5. | Article I PubMed Abstract I PubMed Full Text

23. Pestka S. The human interferon alpha species and receptors. Biopolymers. 2000; 55:254-87. | Article | PubMed

24. Naula C, Parsons $M$ and Mottram JC. Protein kinases as drug targets in trypanosomes and Leishmania. Biochim Biophys Acta. 2005; 1754:1519. | Article | PubMed Abstract | PubMed Full Text

25. Pinna LA. Casein kinase 2: an 'eminence grise' in cellular regulation? Biochim Biophys Acta. 1990; 1054:267-84. | Article | PubMed

\section{Citation:}

Justiniano I, Noris-Suarez K, De Lima AR, Contreras VT and Bubis J. An unusual casein kinase $\mathbf{1}$ from Trypanosoma cruzi epimastigotes. Bio Chem Comp. 2014; 2:1. http://dx.doi.org/10.7243/2052-9341-2-1 